\title{
Hydrolysis and Hydrazinolysis of Isatin-Based Ald- and Ketazines
}

\author{
Hany S. Ibrahim, ${ }^{1}$ Soha R. Abdelhadi, ${ }^{1}$ and Hatem A. Abdel-Aziz ${ }^{2,3}$ \\ ${ }^{1}$ Department of Pharmaceutical Chemistry, Faculty of Pharmacy, Egyptian Russian University, Badr City, Cairo 11829, Egypt \\ ${ }^{2}$ Department of Pharmaceutical Chemistry, College of Pharmacy, King Saud University, P.O. Box 2457, Riyadh 11451, Saudi Arabia \\ ${ }^{3}$ Department of Applied Organic Chemistry, National Research Centre, Dokki, Cairo 12622, Egypt
}

Correspondence should be addressed to Hatem A. Abdel-Aziz; hatem_741@yahoo.com

Received 14 January 2015; Revised 10 April 2015; Accepted 17 April 2015

Academic Editor: Tanaji Talele

Copyright (C) 2015 Hany S. Ibrahim et al. This is an open access article distributed under the Creative Commons Attribution License, which permits unrestricted use, distribution, and reproduction in any medium, provided the original work is properly cited.

The hydrolysis of isatin aldazine 4a-d afforded the unexpected 3,3'-(hydrazine-1,2-diylidene)bis(indolin-2-one) (5) and 1,2di(arylidene)hydrazines $\mathbf{6 a - d}$ through dual hydrolysis of $\mathbf{4 a - d}$. A mechanism to explain the formation of $\mathbf{5}$ and $\mathbf{6 a}-\mathbf{d}$ was proposed. In addition, the hydrazinolysis of $\mathbf{4 a}$-d yielded 3-hydrazonoindolin-2-one (2) and 1,2-di(arylidene)hydrazines $\mathbf{6 a - d}$ instead of hydrazones $\mathbf{1 7 a - d}$, while hydrazinolysis of isatin ketazine 5 gave the expected 3-hydrazonoindolin-2-one (2). These results indicated the ability of the title compounds for unusual hydrolysis and hydrazinolysis reactions.

\section{Introduction}

Isatin imines including Schiff bases $\mathbf{1 b}$ and isatin hydrazones 2, which are the product of condensation of amines or hydrazines with isatins 1a, respectively, are considered as a pharmacophore for diverse spectrum of biological activities [1-5] (Figure 1). They have been reported as anticancer agents where they were found to be inhibitors of tyrosine phosphatase Shp2 [6]. Furthermore, they have been identified as kinase inhibitors and they also have been reported as cytotoxic agents towards U937 lymphoma cells [7]. In addition, hydrazones $2(\mathrm{R}=-\mathrm{COAr})$ revealed a good cytotoxic activity against K562, MDA-MB-468, and HT-29 cell lines [8].

Isatin-based azines $\mathbf{4}$ are usually prepared by the condensation of isatin hydrazones $2\left(\mathrm{R}^{1}=\mathrm{H}\right)$ with aldehydes or ketones 3 to construct the connectivity $>\mathrm{C}=\mathrm{N}-\mathrm{N}=\mathrm{CR}^{2} \mathrm{R}^{3}$ and then the formation of isatin aldazines $\left(4, \mathrm{R}^{2}\right.$ or $\left.\mathrm{R}^{3}=\mathrm{H}\right)$ or isatin ketazines $\left(4, R^{2}\right.$ and $\left.R^{3} \neq H\right)$, respectively (Figure 1 ). Isatin aldazines 4 showed a significant anticancer activity against human breast cell line MCF-7 [9], whereas a series of symmetrical and asymmetrical isatin ketazines 5 showed a selective activity against multidrug-resistant cancer cells [10]. Moreover, bis-Schiff bases of isatins 4 represent significant antiglycation activity [11].
On the other hand, azines undergo hydrolysis to regenerate the hydrazine and aldehydes or ketones. However, ketazines are important intermediates in the production of hydrazine hydrate when subjected to hydrolysis processes [12]. In addition, the reaction of azines with hydrazine (hydrazinolysis) regenerates the hydrazones [13]. In light of the latter results and in continuation of our interest in the chemistry of isatin-based azines 4 and 5, we hope to report herein the unexpected results of hydrolysis and hydrazinolysis of isatin aldazines $\mathbf{4 a - d}$ and isatin ketazines 5.

\section{Experimental}

2.1. General. Melting points were measured with a Stuart melting point apparatus and were uncorrected. IR spectra (KBr disks) were recorded with a Pye Unicam SP 1000 IR spectrophotometer. The NMR spectra were recorded by Varian Gemini-300BB 300 MHz FT-NMR spectrometers (Varian Inc., Palo Alto, CA). ${ }^{1} \mathrm{H}$ and ${ }^{13} \mathrm{C}$ spectra were run at 300 and $75 \mathrm{MHz}$, respectively, in deuterated dimethyl sulfoxide $\left(\mathrm{DMSO}-d_{6}\right)$. Chemical shifts $\left(\delta_{\mathrm{H}}\right)$ are reported relative to TMS as internal standard. All coupling constant $(J)$ values are given in Hertz. Chemical shifts $\left(\delta_{\mathrm{C}}\right)$ are reported relative to 

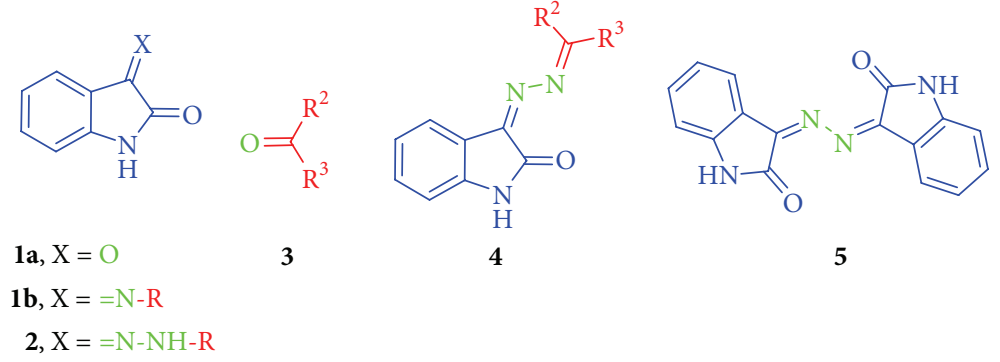

FIgURE 1: General structure of 1-5.

DMSO- $d_{6}$ as internal standards. The abbreviations used are as follows: s: singlet; d: doublet; and m: multiplet. Mass spectra were recorded on Helwett Packard 5988 spectrometer at $70 \mathrm{eV}$. Reaction courses and product mixtures were routinely monitored by thin layer chromatography (TLC) on silica gel precoated $\mathrm{F}_{254}$ Merck plates. Unless otherwise noted, all solvents and reagents were commercially available and were used without further purification.

2.2. Synthesis of Isatin Aldazines $4 \boldsymbol{a}-\boldsymbol{d}$. A mixture of 3hydrazonoindolin-2-one (2) $(0.161 \mathrm{~g}, 1 \mathrm{mmol})$ and aldehyde from $3 \mathrm{a}-\mathrm{c}(1 \mathrm{mmol})$ in acetic acid $(25 \mathrm{~mL})$ was stirred at room temperature for $12 \mathrm{~h}$. The resulted precipitate was filtered, dried, and finally crystallized from EtOH/DMF to afford hydrazones $\mathbf{4 a - c}$, respectively. Aldazines $\mathbf{4 a - d}$ were also prepared by the reaction of $\mathbf{2}$ with $\mathbf{3} \mathbf{a}-\mathbf{d}$ in refluxing ethanol, in the presence of catalytic amount of glacial acetic acid for $6 \mathrm{~h} \mathrm{[10].}$

2.2.1. 3-((Benzylidene)hydrazono)indolin-2-one (4a). Yield $(62 \%), \mathrm{mp}>300^{\circ} \mathrm{C}$ (lit. $\left.\mathrm{mp} 300^{\circ} \mathrm{C}[14]\right)$; IR (KBr) v 3280 $(\mathrm{NH}), 1722(\mathrm{C}=\mathrm{O}), 1614(\mathrm{C}=\mathrm{N}) \mathrm{cm}^{-1} ;{ }^{1} \mathrm{H}$ NMR (DMSO$\left.d_{6}\right) \delta 6.90(\mathrm{~d}, 1 \mathrm{H}, J=7.8 \mathrm{~Hz}, \mathrm{H} 4$ of isatin), $7.04(\mathrm{t}, 1 \mathrm{H}, J=$ $7.5 \mathrm{~Hz}, \mathrm{H} 5$ of isatin), 7.42 (t, 1H, $J=7.5 \mathrm{~Hz}, \mathrm{H} 6$ of isatin), 7.51 (d, $1 \mathrm{H}, J=7.8 \mathrm{~Hz}, \mathrm{H} 7$ of isatin), 7.57-7.99 (m, 5H, Ar-H), $8.61(\mathrm{~s}, 1 \mathrm{H}, \mathrm{N}=\mathrm{CH}), 10.97$ ( $\mathrm{s}, \mathrm{D}_{2} \mathrm{O}$ exchangeable, $1 \mathrm{H}, \mathrm{NH}$ ); ${ }^{13} \mathrm{C}$ NMR (DMSO- $\left.d_{6}\right) \delta 110.95,111.19,115.73,122.39,122.63$, $128.03,128.25,134.26,134.47,144.70,145.16,163.36(\mathrm{C}=\mathrm{O})$; $\mathrm{MS}$ $\mathrm{m} / z(\%) 249\left(\mathrm{M}^{+}, 30.02\right), 221$ (17.03), 145 (35.41).

2.2.2. 3-((4-Nitrobenzylidene)hydrazono)indolin-2-one (4b) [11]. Yield (66\%), mp 254-256 ${ }^{\circ} \mathrm{C}$; IR (KBr) v $3161(\mathrm{NH}), 1734$ $(\mathrm{C}=\mathrm{O}), 1616(\mathrm{C}=\mathrm{N}) \mathrm{cm}^{-1} ;{ }^{1} \mathrm{H} \mathrm{NMR}\left(\mathrm{DMSO}-d_{6}\right) \delta 6.90(\mathrm{~d}, 1 \mathrm{H}$, $J=7.8 \mathrm{~Hz}, \mathrm{H} 4$ of isatin), $7.01(\mathrm{t}, 1 \mathrm{H}, J=7.5 \mathrm{~Hz}, \mathrm{H} 5$ of isatin), $7.41(\mathrm{t}, 1 \mathrm{H}, J=7.5 \mathrm{~Hz}, \mathrm{H} 6$ of isatin), $7.73(\mathrm{~d}, 1 \mathrm{H}, J=7.8 \mathrm{~Hz}$, $\mathrm{H} 7$ of isatin), $8.20(\mathrm{~d}, 2 \mathrm{H}, J=8.7 \mathrm{~Hz}, \mathrm{Ar}-\mathrm{H}), 8.37(\mathrm{~d}, 2 \mathrm{H}, J=$ 8.7, $\mathrm{Ar}-\mathrm{H}), 8.66$ ( $\mathrm{s}, 1 \mathrm{H}, \mathrm{N}=\mathrm{CH}), 10.86$ ( $\mathrm{s}, \mathrm{D}_{2} \mathrm{O}$ exchangeable, $1 \mathrm{H}, \mathrm{NH}) ;{ }^{13} \mathrm{C}$ NMR (DMSO- $\left.d_{6}\right) \delta 110.85,111.08,116.01,122.29$, $122.53,124.23,128.59,128.78,129.64,133.98,134.19,139.06$, $145.27,148.97,149.67,156.21,156.35,164.10(\mathrm{C}=\mathrm{O}) ; \mathrm{MS} m / z(\%)$ $294\left(\mathrm{M}^{+}, 10.49\right), 266(100)$.

2.2.3. 3-((4-Chlorobenzylidene)hydrazono)indolin-2-one (4c). Yield $(78 \%), \mathrm{mp}=270-272^{\circ} \mathrm{C}$ (lit. $\mathrm{mp}=200^{\circ} \mathrm{C}$ [14]); IR $(\mathrm{KBr})$ v $3248(\mathrm{NH}), 1734(\mathrm{C}=\mathrm{O}), 1604(\mathrm{C}=\mathrm{N}) \mathrm{cm}^{-1}$; ${ }^{1} \mathrm{H}$ NMR
$\left(\mathrm{DMSO}-d_{6}\right) \delta 6.90(\mathrm{~d}, 1 \mathrm{H}, J=7.5 \mathrm{~Hz}, \mathrm{H} 4$ of isatin), $7.02(\mathrm{t}, 1 \mathrm{H}$, $J=7.8 \mathrm{~Hz}, \mathrm{H} 5$ of isatin), $7.41(\mathrm{t}, 1 \mathrm{H}, J=7.8 \mathrm{~Hz}, \mathrm{H} 6$ of isatin), $7.63(\mathrm{~d}, 2 \mathrm{H}, J=8.4 \mathrm{~Hz}, \mathrm{Ar}-\mathrm{H}), 7.85(\mathrm{~d}, 1 \mathrm{H}, J=7.5 \mathrm{~Hz}, \mathrm{H} 7$ of isatin), $7.98(\mathrm{~d}, 2 \mathrm{H}, J=8.4, \mathrm{Ar}-\mathrm{H}), 8.61(\mathrm{~s}, 1 \mathrm{H}, \mathrm{N}=\mathrm{CH})$, $10.86\left(\mathrm{~s}, \mathrm{D}_{2} \mathrm{O}\right.$ exchangeable, $\left.1 \mathrm{H}, \mathrm{NH}\right) ;{ }^{13} \mathrm{C}$ NMR (DMSO- $d_{6}$ ) $\delta 110.73,110.98,116.26,128.82,129.23,130.37,130.45,132.24$, $133.92,136.65,141.72,145.07,150.29,158.75,164.35$ (C=O); MS $m / z(\%) 285\left(\mathrm{M}^{+}+2,6.78\right), 283\left(\mathrm{M}^{+}, 20.10\right), 255$ (89.86), 145 (16.96), 138 (54.66), 111 (95.01).

2.2.4. 3-((4-Methoxybenzylidene)hydrazono)indolin-2-one (4d). Yield (69\%), $\mathrm{mp}=182-183^{\circ} \mathrm{C}$ (lit. $\mathrm{mp}=182^{\circ} \mathrm{C}$ [14]); IR $(\mathrm{KBr}) v 3194(\mathrm{NH}), 1732(\mathrm{C}=\mathrm{O}), 1606(\mathrm{C}=\mathrm{N}) \mathrm{cm}^{-1} ;{ }^{1} \mathrm{H}$ NMR $\left(\mathrm{DMSO}_{6}\right) \delta 3.87\left(\mathrm{~s}, 6 \mathrm{H}, 2 \mathrm{OCH}_{3}\right), 6.89(\mathrm{~d}, 1 \mathrm{H}, J=7.5 \mathrm{~Hz}$, $\mathrm{H} 4$ of isatin), 7.04 (t, $1 \mathrm{H}, J=7.8 \mathrm{~Hz}, \mathrm{H} 5$ of isatin), 7.12 (d, $2 \mathrm{H}$, $J=8.4, \operatorname{Ar}-\mathrm{H}), 7.39$ (t, $1 \mathrm{H}, J=7.5 \mathrm{~Hz}, \mathrm{H6}$ of isatin), 7.94 (d, $2 \mathrm{H}, J=8.4 \mathrm{~Hz}, \mathrm{Ar}-\mathrm{H}), 8.02(\mathrm{~d}, 1 \mathrm{H}, J=7.8 \mathrm{~Hz}, \mathrm{H} 7$ of isatin), $8.61(\mathrm{~s}, 1 \mathrm{H}, \mathrm{N}=\mathrm{CH}), 10.76$ ( $\mathrm{s}, \mathrm{D}_{2} \mathrm{O}$ exchangeable, $1 \mathrm{H}, \mathrm{NH}$ ); ${ }^{13} \mathrm{C}$ NMR (DMSO- $\left.d_{6}\right) \delta 55.55\left(\mathrm{OCH}_{3}\right), 110.58,110.81,114.62$, $114.87,116.59,122.13,122.36,126.32,128.79,128.86,130.91$, $131.03,133.29,133.52,144.80,145.15,150.65,161.81,161.93$, $162.58,163.36,164.69$ (C=O); MS m/z (\%) $279\left(\mathrm{M}^{+}, 30.31\right)$, 251 (100), 134 (17.79).

\subsection{Hydrolysis of Isatin Aldazines $4 \boldsymbol{a}-\boldsymbol{d}$}

Method A. A solution of isatin aldazines $4 \mathbf{a}-\mathbf{d}(1 \mathrm{mmol})$ in $\mathrm{H}_{2} \mathrm{O} / \mathrm{AcOH}(1: 3, \mathrm{v}: \mathrm{v}, 25 \mathrm{~mL})$ was refluxed for $4 \mathrm{~h}$. The given $3,3^{\prime}$-(hydrazine-1,2-diylidene)bis(indolin-2-one) (5) was filtered while hot and crystallized from EtOH/DMF. The filtrate of the latter reaction was concentrated. The solid formed was washed with $50 \%$ ethanol, dried, and crystallized from EtOH to give 1,2-di(arylidene)hydrazines 6a-d. The physical constants of $\mathbf{5}$ and $\mathbf{6 a - d}$ were identical with that reported.

Method B. A mixture of 3-hydrazonoindolin-2-one (2) $(0.161 \mathrm{~g}, 1 \mathrm{mmol})$ and the appropriate aldehyde from 3a-c (1 mmol) in $\mathrm{H}_{2} \mathrm{O} / \mathrm{AcOH}(1: 3, \mathrm{v}: \mathrm{v}, 25 \mathrm{~mL})$ was refluxed for $4 \mathrm{~h}$. Ketazine 5 was filtered while hot and crystallized from EtOH/DMF while aldazines $\mathbf{6 a - d}$ were isolated from the filtrate after evaporation of the solvent.

2.3.1. 3,3'-(Hydrazine-1,2-diylidene)diindolin-2-one (5) [8]. Yield $(46 \%), \mathrm{mp}>300^{\circ} \mathrm{C}$; IR $(\mathrm{KBr}) v 3276(2 \mathrm{NH}), 1722$ $(2 \mathrm{C}=\mathrm{O}), 1615(2 \mathrm{C}=\mathrm{N}) \mathrm{cm}^{-1} ;{ }^{1} \mathrm{H}$ NMR $\left(\mathrm{DMSO}-d_{6}\right) \delta 6.82(\mathrm{~d}$, 


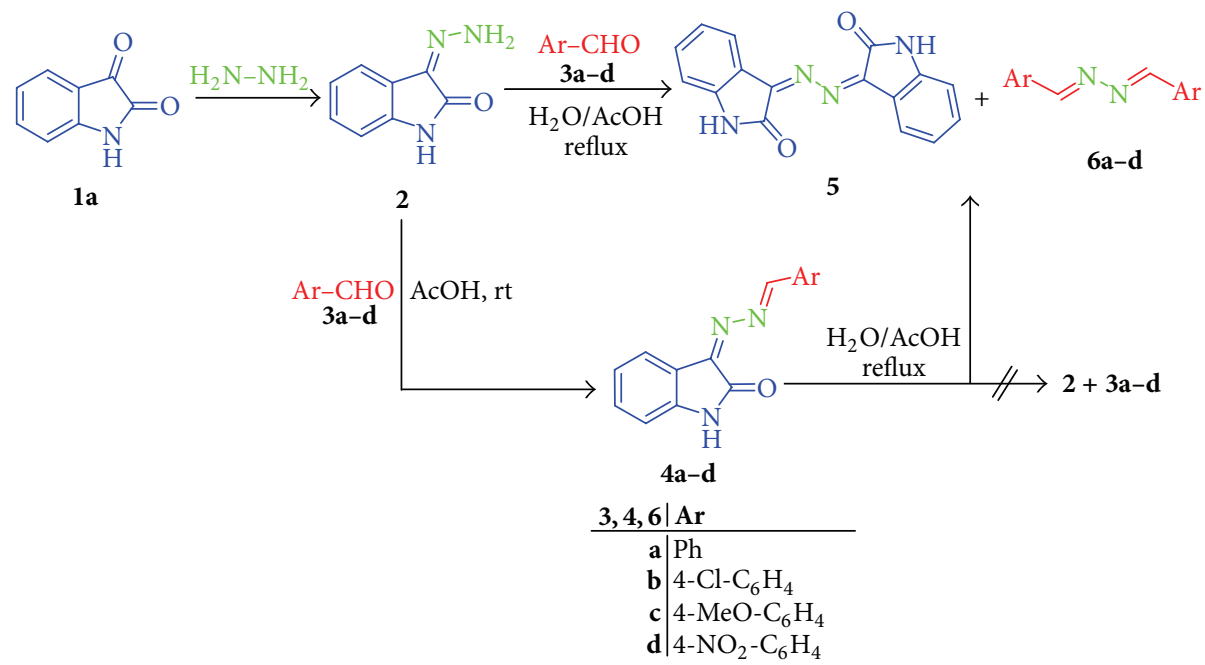

SCHeme 1: The reaction of 3-hydrazonoindolin-2-one (2) with aldehydes 3a-d.

$2 \mathrm{H}, J=7.8 \mathrm{~Hz}, \mathrm{H} 5$ of isatin), $6.96(\mathrm{t}, 2 \mathrm{H}, J=7.5 \mathrm{~Hz}, \mathrm{H} 6$ of isatin), $7.14(\mathrm{t}, 2 \mathrm{H}, J=7.5 \mathrm{~Hz}, \mathrm{H} 7$ of isatin), $7.34(\mathrm{~d}, 2 \mathrm{H}$, $J=7.8 \mathrm{~Hz}, \mathrm{H} 4$ of isatin), 10.55 (s, $\mathrm{D}_{2} \mathrm{O}$ exchangeable, $2 \mathrm{H}$, $2 \mathrm{NH}) ;{ }^{13} \mathrm{C}$ NMR $\left(\mathrm{DMSO}-d_{6}\right) \delta 111.59,116.26,123.03,128.66$, $134.89,145.22,145.68,163.89(2 \mathrm{C}=\mathrm{O})$.

2.3.2. 1,2-Di(benzylidene)hydrazine (6a). Yield (70\%), $\mathrm{mp}=$ 95-97 $\mathrm{C}\left(\right.$ Lit. $\left.\mathrm{mp}=92-93^{\circ} \mathrm{C}[15]\right)$. IR $1615-1620(2 \mathrm{C}=\mathrm{N}) \mathrm{cm}^{-1}$; ${ }^{1} \mathrm{H}$ NMR (DMSO- $d_{6}$ ) $\delta 7.57-7.99(\mathrm{~m}, 10 \mathrm{H}, \mathrm{Ar}-\mathrm{H}), 8.61$ (s, 2H, $\mathrm{N}=\mathrm{CH}) ; \mathrm{MS} \mathrm{m} / z(\%) 209\left(\mathrm{M}^{+}+1,11.68\right), 208\left(\mathrm{M}^{+}, 79.43\right), 207$ (100), 138 (100).

2.3.3. 1,2-Bis(-4-chlorobenzylidene)hydrazine (6b). Yield $(82 \%), \mathrm{mp}=211-213^{\circ} \mathrm{C}\left(\right.$ Lit. $\mathrm{mp}=207-208^{\circ} \mathrm{C}$ [15]) IR 1617$1625(2 \mathrm{C}=\mathrm{N}) \mathrm{cm}^{-1} ;{ }^{1} \mathrm{H}$ NMR (DMSO-d 6$) \delta 7.56(\mathrm{~d}, 4 \mathrm{H}$, $J=8.4 \mathrm{~Hz}, \mathrm{Ar}-\mathrm{H}), 7.88$ (d, $4 \mathrm{H}, J=8.4 \mathrm{~Hz}, \mathrm{Ar}-\mathrm{H}), 8.61$ (s, $2 \mathrm{H}, \mathrm{N}=\mathrm{CH}) ;{ }^{13} \mathrm{C}$ NMR (DMSO- $\left.d_{6}\right) \delta 128.93,129.89,132.56$, 135.791, $160.44(2 \mathrm{C}=\mathrm{N}) ; \mathrm{MS} m / z(\%) 279\left(\mathrm{M}^{+}+2,9.68\right), 277$ $\left(\mathrm{M}^{+}, 31.14\right), 165$ (100), 138 (23.01), 111 (34.85).

2.3.4. 1,2-Bis(4-methoxybenzylidene)hydrazine (6c). Yield (77\%), $\mathrm{mp}=170-172^{\circ} \mathrm{C}\left(\right.$ Lit. $\mathrm{mp}=175^{\circ} \mathrm{C}$ [15]) IR 1615-1622 $(2 \mathrm{C}=\mathrm{N}) \mathrm{cm}^{-1} ;{ }^{1} \mathrm{H}$ NMR (DMSO- $\left.d_{6}\right) \delta 3.83\left(\mathrm{~s}, 6 \mathrm{H}, \mathrm{OCH}_{3}\right)$, $7.04(\mathrm{~d}, 4 \mathrm{H}, J=8.4 \mathrm{~Hz}, \mathrm{Ar}-\mathrm{H}), 7.79(\mathrm{~d}, 4 \mathrm{H}, J=8.4 \mathrm{~Hz}, \mathrm{Ar}-\mathrm{H})$, $8.61(\mathrm{~s}, 2 \mathrm{H}, \mathrm{N}=\mathrm{CH}) ;{ }^{13} \mathrm{C} \mathrm{NMR}\left(\mathrm{DMSO}-d_{6}\right) \delta 55.27\left(2 \mathrm{OCH}_{3}\right)$, $114.23,126.53,129.83,160.35,161.62(2 \mathrm{C}=\mathrm{N})$; MS $m / z(\%) 268$ $\left(\mathrm{M}^{+}, 18.37\right), 161$ (31.72), 134 (26.80), 107 (16.07).

2.3.5. 1,2-Bis(4-nitrobenzylidene)hydrazine (6d). Yield (74\%), $\mathrm{mp}=223-225^{\circ} \mathrm{C}\left(\right.$ Lit. $\mathrm{mp}=223.3-223.4^{\circ} \mathrm{C}$ [16] $)$ IR 1610-1617 $(2 \mathrm{C}=\mathrm{N}) \mathrm{cm}^{-1} ;{ }^{1} \mathrm{H} \mathrm{NMR}\left(\mathrm{DMSO}-d_{6}\right) \delta 7.55(\mathrm{~d}, 4 \mathrm{H}, J=8.4 \mathrm{~Hz}$, Ar-H), 7.88 (d, $4 \mathrm{H}, J=8.4 \mathrm{~Hz}, \mathrm{Ar}-\mathrm{H}), 8.60$ (s, $2 \mathrm{H}, \mathrm{N}=\mathrm{CH})$; MS m/z 272 (\%) $298\left(\mathrm{M}^{+}, 10.03\right), 252$ (100), 176 (50.55).

2.4. Hydrazinolysis of $\mathbf{4 a}-\boldsymbol{d}$. To a solution of hydrazones $\mathbf{4 a -}$ d $(1 \mathrm{mmol})$ in ethanol $(25 \mathrm{~mL})$, hydrazine hydrate $(0.06 \mathrm{~g}$ $0.12 \mathrm{mmol}$ ) was added. The reaction was refluxed for $5 \mathrm{~h}$.
The formed precipitate was filtered, washed with ethanol, dried, and finally crystallized from EtOH/DMF to give 3hydrazonoindolin-2-one (2) with $\mathrm{mp}=217-219^{\circ} \mathrm{C}$ (Lit. $\mathrm{mp}$ $\left.=219-220^{\circ} \mathrm{C}[16]\right)$; IR (KBr) v 3361-3215 $\left(\mathrm{NH}, \mathrm{NH}_{2}\right), 1687$ $(\mathrm{C}=\mathrm{O}), 1608(\mathrm{C}=\mathrm{N}) \mathrm{cm}^{-1} ;{ }^{1} \mathrm{H}$ NMR $\left(\mathrm{DMSO}-d_{6}\right) \delta 6.87(\mathrm{~d}, 1 \mathrm{H}$, $J=7.5$; Hz, H5 of isatin), 6.97 (t, $1 \mathrm{H}, J=7.8 \mathrm{~Hz}, \mathrm{H} 6$ of isatin), $7.15(\mathrm{t}, 1 \mathrm{H}, J=7.8 \mathrm{~Hz}, \mathrm{H} 7$ of isatin), $7.37(\mathrm{~d}, 1 \mathrm{H}, J=7.5 \mathrm{~Hz}$, $\mathrm{H} 4$ isatin), $9.55\left(\mathrm{~d}, 1 \mathrm{H}, J=14.0 \mathrm{~Hz}, \mathrm{D}_{2} \mathrm{O}\right.$ exch., amino $\left.\mathrm{H}\right)$, 10.56 (d, $1 \mathrm{H}, J=14.0 \mathrm{~Hz}, \mathrm{D}_{2} \mathrm{O}$ exch., amino $\mathrm{H}$ ), 10.72 (s, $\mathrm{D}_{2} \mathrm{O}$ exch., $1 \mathrm{H}, \mathrm{NH}$ isatin); MS $m / z(\%) 161.1\left(\mathrm{M}^{+}\right)$. The filtrate was evaporated under vacuum. The obtained residue was filtered, washed with 50\% ethanol, dried, and crystallized from EtOH to yield 1,2-di(arylidene)hydrazines $\mathbf{6 a - d}$.

2.5. Hydrazinolysis of 5 . To a solution of $5(0.29 \mathrm{~g}, 1 \mathrm{mmol})$ in ethanol $(25 \mathrm{~mL})$, hydrazine hydrate $(0.06 \mathrm{~g} 0.12 \mathrm{mmol})$ was added. The reaction was refluxed for $5 \mathrm{~h}$. The formed precipitate was filtered, washed with ethanol, dried, and finally crystallized from EtOH/DMF to give hydrazonoindolin-2one (2).

\section{Results and Discussion}

In the reaction of 3-hydrazonoindolin-2-one $(2)(\mathrm{R}=\mathrm{H})$ with aldehydes $\mathbf{3 a - d}$ in glacial acetic acid for $12 \mathrm{~h}$, at ambient temperature, isatin aldazines $\mathbf{4 a - d}$ were isolated extensively. The targeted aldazines $\mathbf{4 a - d}$ were also prepared by the reaction of 3-hydrazonoindolin-2-one (2) with aldehydes 3a$\mathbf{d}$ in refluxing ethanol, in the presence of catalytic amount of glacial acetic acid for $6 \mathrm{~h}$ (Scheme 1) [9].

Hydrolysis of hydrazones $\mathbf{4 a - d}$ by their refluxing in $\mathrm{H}_{2} \mathrm{O} / \mathrm{AcOH}$ afforded reddish precipitates during reflux in each case. These precipitates showed identical physical and chemical properties and they are not matched with the expected hydrazone $2(\mathrm{R}=\mathrm{H})$ (Scheme 1$)$.

The ${ }^{1} \mathrm{H}$ NMR spectrum of the isolated precipitate did not show the characteristic signal of $\mathrm{NH}_{2}$ of $\mathbf{2}$ and its mass 


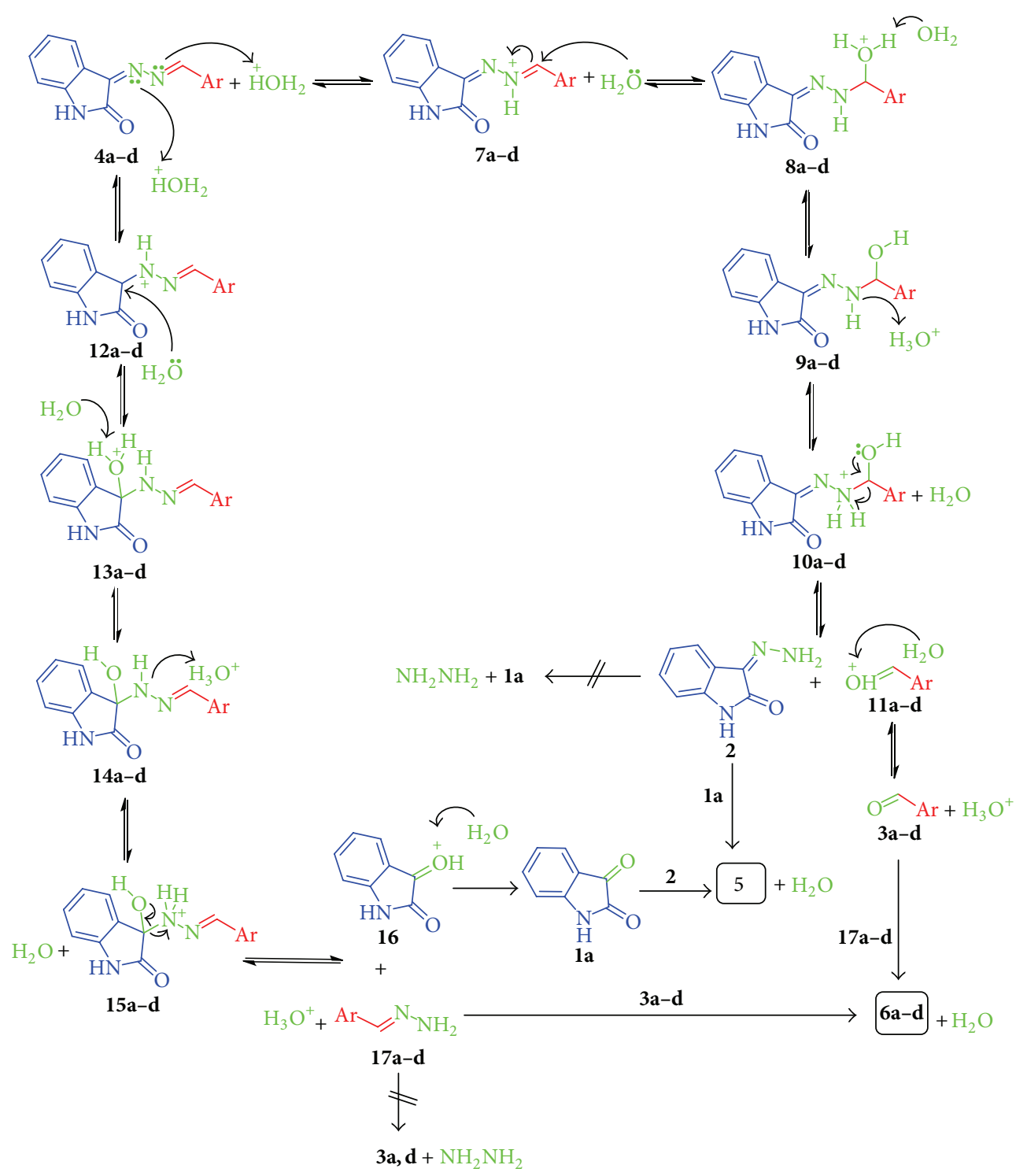

FIGURE 2: The proposed mechanism for the hydrolysis of isatin aldazines $\mathbf{4 a - d}$ in refluxing $\mathrm{H}_{2} \mathrm{O} / \mathrm{AcOH}$.

spectrum exhibited molecular ion peak at $m / z=290$. The latter data proposed the assigned structure $3,3^{\prime}$-(hydrazine-1,2diylidene)bis(indolin-2-one) (5) for the isolated compound. An authentic sample of compound 5 is prepared [10] and it was identical in all respects with the isolated compound in our hands.

After evaporation of the filtrates of the latter reactions, they gave in each case a compound with melting points $97^{\circ} \mathrm{C}(\mathrm{Ar}=\mathrm{Ph}), 213^{\circ} \mathrm{C}\left(\mathrm{Ar}=4-\mathrm{Cl}_{-} \mathrm{C}_{6} \mathrm{H}_{4}\right), 172^{\circ} \mathrm{C}(\mathrm{Ar}=$ $\left.4-\mathrm{MeO}-\mathrm{C}_{6} \mathrm{H}_{4}\right)$, and $225^{\circ} \mathrm{C}\left(\mathrm{Ar}=4-\mathrm{NO}_{2}-\mathrm{C}_{6} \mathrm{H}_{4}\right)$, respectively. These values do not match this reported for 2, 217$219^{\circ} \mathrm{C}$. Our attempts to explore these unknown compounds guided us to assign structure 1,2-di(arylidene)hydrazines 6ad for the isolated compounds. We found that the analytical data of authentic samples of isolated compounds is identical with those of $\mathbf{6 a - d}$ [17-20]. Interestingly, refluxing
2 with aldehydes $3 \mathbf{a}-\mathbf{d}$ in $\mathrm{H}_{2} \mathrm{O} / \mathrm{AcOH}, 3,3^{\prime}$-(hydrazine-1,2diylidene)bis(indolin-2-one) (5) and aldazines $\mathbf{6 a - d}$ were also isolated.

Keeping in mind the reported data about the mechanism of hydrolysis of $-\mathrm{C}=\mathrm{N}$ - imines [21], we are interested in proposing a mechanism to explain the formation of 3,3' -(hydrazine-1,2-diylidene)bis(indolin-2-one) (5) and 1,2-di(arylidene)hydrazines $\mathbf{6 a - d}$. In this mechanism, dual acidic hydrolysis of aldazines $\mathbf{4 a - d}$ took place in their two nucleophilic centers which are accessible to attack by two protons from the acidic medium (Figure 2). The first pathway, in which acidic proton attack took place by the nitrogen of $-\mathrm{N}=\mathrm{C}-\mathrm{Ar}$ followed by hydrolysis to give intermediates $\mathbf{7}(\mathbf{a}-\mathbf{d})-\mathbf{1 0}(\mathbf{a}-\mathbf{d})$, respectively, yielded aldehydes $\mathbf{3 a - d}$ and 3-hydrazonoindolin-2-ones (2) which would not undergo further hydrolysis. The second pathway, in which the other 

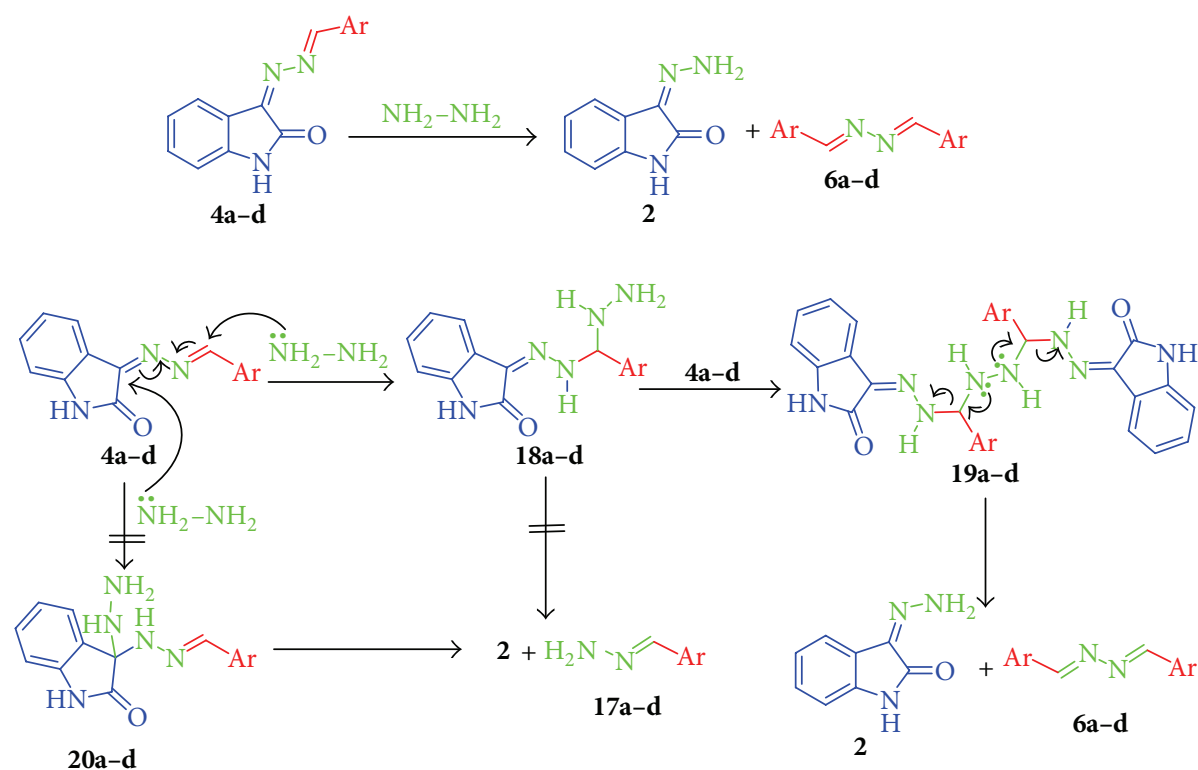

SCHeme 2: Hydrazinolysis of aldazines 4a-d.

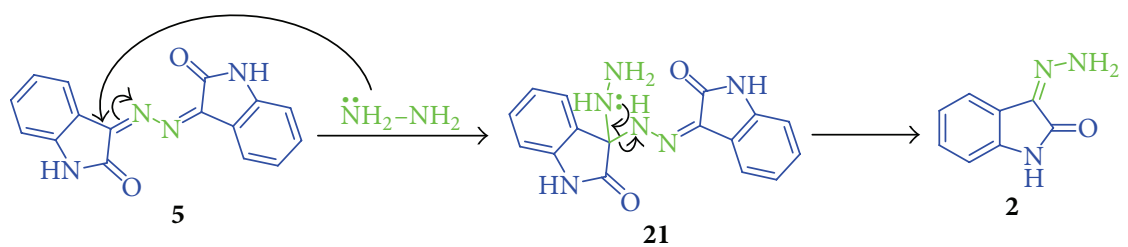

SCHEME 3: Hydrazinolysis of 3,3' -(hydrazine-1,2-diylidene)bis(indolin-2-one) (5).

nitrogen of hydrazone function attacked the acidic proton followed by hydrolysis to give intermediates $\mathbf{1 2}(\mathbf{a}-\mathrm{d})-\mathbf{1 5}(\mathbf{a}-$ d), respectively, yielded indoline-2,3-dione (1) and the corresponding hydrazones $\mathbf{1 7 a - d}$ without further hydrolysis. Finally, the reaction of $\mathbf{1 a}$ with $\mathbf{2}(\mathrm{R}=\mathrm{H})$ and $\mathbf{3 a - d}$ with $\mathbf{1 7} \mathbf{a}-$ d led to the formation of final products $3,3^{\prime}$-(hydrazine-1,2diylidene)bis(indolin-2-one) (5) and aldazines 6a-d, respectively. The expected last step is hydrolysis of $2(\mathrm{R}=\mathrm{H})$ and/or 17a-d.

According to the previous results and in light of behavior of hydrazine hydrate towards certain $-\mathrm{N}=\mathrm{N}$ - containing compounds [12], we stimulated to explore the reactivity of hydrazine hydrate towards $-\mathrm{N}=\mathrm{C}$ - function in aldazines $4 \mathbf{a}-$ d. Thus, the reaction of $\mathbf{4 a - d}$ with hydrazine hydrate in refluxing ethanol afforded 3-hydrazonoindolin-2-one (2) and 1,2-di(arylidene)hydrazines $\mathbf{6 a - d}$, respectively, instead of $\mathbf{2}$ and $\mathbf{1 7} \mathbf{a}-\mathbf{d}$ (Scheme 2).

Hydrazine, as a nucleophile, attacked the carbon of $-\mathrm{N}=\mathrm{C}-$ function of two molecules of hydrazones $4 \mathbf{a}-\mathbf{d}$ to form the nonisolable intermediates $18 \mathbf{a}-\mathbf{d}$ and $19 \mathbf{a}-\mathbf{d}$, respectively (Scheme 3). Finally, the nonisolable intermediate 19a-d afforded 3-hydrazonoindolin-2-one (2) and 1,2di(arylidene)hydrazines $\mathbf{6 a - d}$ as final isolated compounds.

Consequently, the reaction of hydrazine hydrate with C-3 of $3,3^{\prime}$-(hydrazine-1,2-diylidene)bis(indolin-2-one) (5) yielded the corresponding 3-hydrazonoindolin-2-one (2) as hydrazinolysis product (Scheme 3 ). The previous reaction proceeded through the attack of nucleophilic nitrogen of hydrazine on ketazine 5 to form the nonisolable intermediate 21 and then the formation of 3-hydrazonoindolin-2-one (2).

\section{Conclusion}

In conclusion, we reported herein the hydrolysis of isatin aldazines $4 \mathbf{a}-\mathbf{d}$ which gave unusual product $3,3^{\prime}$-(hydrazine1,2-diylidene)bis(indolin-2-one) (5) and aldazines 6a-d were formed through dual acidic hydrolysis. The hydrazinolysis of isatin aldazines $\mathbf{4 a - d}$ yielded 3-hydrazonoindolin-2-one (2) and $\mathbf{6 a - d}$ instead of $\mathbf{1 7} \mathbf{a}-\mathbf{d}$. These results established the ability of the title compounds for unusual hydrolysis and hydrazinolysis reactions.

\section{Conflict of Interests}

The authors have declared that there is no conflict of interests.

\section{Acknowledgments}

The authors would like to extend their sincere appreciation to the Deanship of Scientific Research at King Saud University for its funding of this research through the Research Group Project no. RGP-VPP-321. Department of Pharmaceutical 
Chemistry, Faculty of Pharmacy, Egyptian Russian University, Cairo, Egypt, is highly appreciated for supporting this research.

\section{References}

[1] S. K. Sridhar, M. Saravanan, and A. Ramesh, "Synthesis and antibacterial screening of hydrazones, Schiff and Mannich bases of isatin derivatives," European Journal of Medicinal Chemistry, vol. 36, no. 7-8, pp. 615-625, 2001.

[2] A. Jarrahpour, J. Sheikh, I. E. Mounsi, H. Juneja, and T. B. Hadda, "Computational evaluation and experimental in vitro antibacterial, antifungal and antiviral activity of bis-Schiff bases of isatin and its derivatives," Medicinal Chemistry Research, vol. 22, no. 3, pp. 1203-1211, 2013.

[3] T. N. Akhaja and J. P. Raval, "1,3-dihydro-2H-indol-2-ones derivatives: design, Synthesis, in vitro antibacterial, antifungal and antitubercular study," European Journal of Medicinal Chemistry, vol. 46, no. 11, pp. 5573-5579, 2011.

[4] M. Verma, S. N. Pandeya, K. N. Singh, and J. P. Stables, "Anticonvulsant activity of Schiff bases of isatin derivatives," Acta Pharmaceutica, vol. 54, no. 1, pp. 49-56, 2004.

[5] S. K. Sridhar, S. N. Pandeya, J. P. Stables, and A. Ramesh, "Anticonvulsant activity of hydrazones, Schiff and Mannich bases of isatin derivatives," European Journal of Pharmaceutical Sciences, vol. 16, no. 3, pp. 129-132, 2002.

[6] H. R. Lawrence, R. Pireddu, L. Chen et al., "Inhibitors of Src homology-2 domain containing protein tyrosine phosphatase2 (Shp2) based on oxindole scaffolds," Journal of Medicinal Chemistry, vol. 51, no. 16, pp. 4948-4956, 2008.

[7] A. H. Abadi, S. M. Abou-Seri, D. E. Abdel-Rahman, C. Klein, O. Lozach, and L. Meijer, "Synthesis of 3-substituted-2-oxoindole analogues and their evaluation as kinase inhibitors, anticancer and antiangiogenic agents," European Journal of Medicinal Chemistry, vol. 41, no. 3, pp. 296-305, 2006.

[8] H. A. Abdel-Aziz, T. Elsaman, A. Al-Dhfyan, M. I. Attia, K. A. Al-Rashood, and A.-R. M. Al-Obaid, "Synthesis and anticancer potential of certain novel 2-oxo- $N^{\prime}$-(2-oxoindolin- 3-ylidene)$2 \mathrm{H}$-chromene-3-carbohydrazides," European Journal of Medicinal Chemistry, vol. 70, pp. 358-363, 2013.

[9] H. E. Dweedar, H. Mahrous, H. S. Ibrahim, and H. A. AbdelAziz, "Analogue-based design, synthesis and biological evaluation of 3-substituted-(methylenehydrazono)indolin-2-ones as anticancer agents," European Journal of Medicinal Chemistry, vol. 78, pp. 275-280, 2014.

[10] T. A. F. M. Hassan, A. A. Kadi, and H. A. K. Abdel-Aziz, "Novel N, N'-Hydrazino-bis-isatin Derivatives with Selective Activity against Multidrug-Resistant Cancer Cells," US Patents, US20120252860, 2012.

[11] K. M. Khan, M. Khan, M. Ali et al., "Synthesis of bis-Schiff bases of isatins and their antiglycation activity, Bioorganic \& Medicinal Chemistry, vol. 17, no. 22, pp. 7795-7801, 2009.

[12] E. C. Gilbert, "Studies on hydrazine. the hydrolysis of dimethylketazine and the equilibrium between hydrazine and acetone," Journal of the American Chemical Society, vol. 51, no. 11, pp. 3394-3409, 1929.

[13] A. C. Day and M. C. Whiting, "Acetone hydrazone," Organic Syntheses, vol. 50, p. 3, 1970.

[14] V. K. Sharma, S. Srivastava, and A. Srivastava, "Novel coordination complexes of the trivalent ruthenium, rhodium and iridium with hydrazones derived from isatin hydrazide and various aldehydes with spectral and biological characterization," Polish Journal of Chemistry, vol. 80, no. 3, pp. 387-396, 2006.

[15] H. Eshghi and M. Hosseini, "Selective and convenient protection of aldehydes as azines under solvent-free conditions," Journal of the Chinese Chemical Society, vol. 55, no. 3, pp. 636$638,2008$.

[16] S. Okumura, C.-H. Lin, Y. Takeda, and S. Minakata, "Oxidative dimerization of (hetero)aromatic amines utilizing t-BuOI leading to (hetero)aromatic azo compounds: scope and mechanistic studies," The Journal of Organic Chemistry, vol. 78, no. 23, pp. 12090-12105, 2013.

[17] K. M. Khan, W. Jamil, N. Ambreen, M. Taha, S. Perveen, and G. A. Morales, "An expeditious synthetic approach towards the synthesis of Bis-Schiff bases (aldazines) using ultrasound," Ultrasonics Sonochemistry, vol. 21, no. 3, pp. 1200-1205, 2014.

[18] A.-F. E. Mourad, "Charge-transfer complexes of heterocyclic azines with $\Pi$-acceptors," Spectrochimica Acta Part A, vol. 41, no. 1-2, pp. 347-350, 1985.

[19] K. Saito and H. Ishihara, "Thermolysis of sodium salts of tosylhydrazones of some heterocyclic aldehydes in the presence of silver chromate: $1,3 \mathrm{~N} \rightarrow \mathrm{C}$ migration of tosyl group," Heterocycles, vol. 26, no. 7, pp. 1891-1898, 1987.

[20] L. Yang, X. Shan, Q. Chen, Z. Wang, and J. S. Ma, "The first silver(I) side-on $\eta 2$-coordination network formed by self-assembly of bis(pyrrol-2-ylmethylene)hydrazine," European Journal of Inorganic Chemistry, no. 7, pp. 1474-1477, 2004.

[21] E. H. Cordes and W. P. Jencks, "The mechanism of hydrolysis of Schiff bases derived from aliphatic amines," Journal of the American Chemical Society, vol. 85, no. 18, pp. 2843-2848, 1963. 

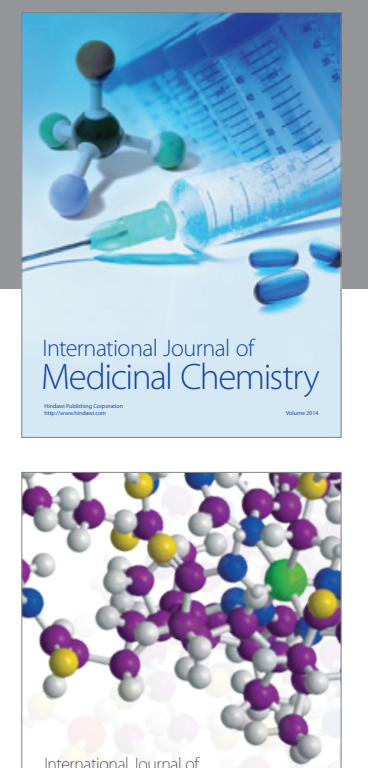

\section{Carbohydrate} Chemistry

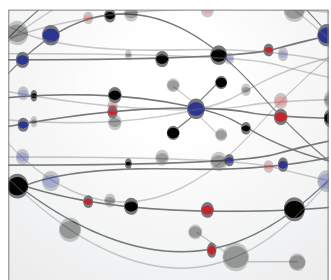

The Scientific World Journal
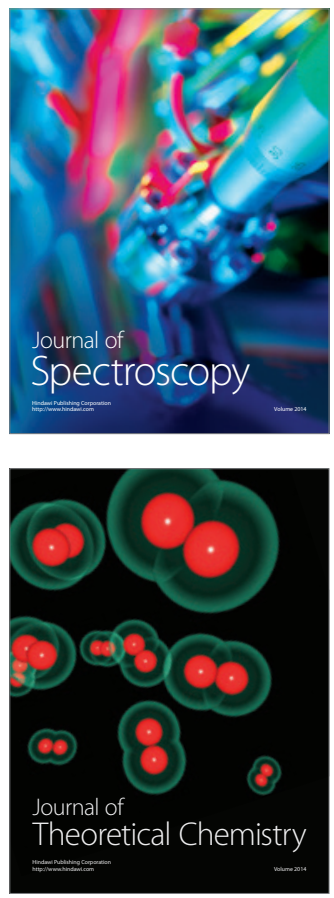
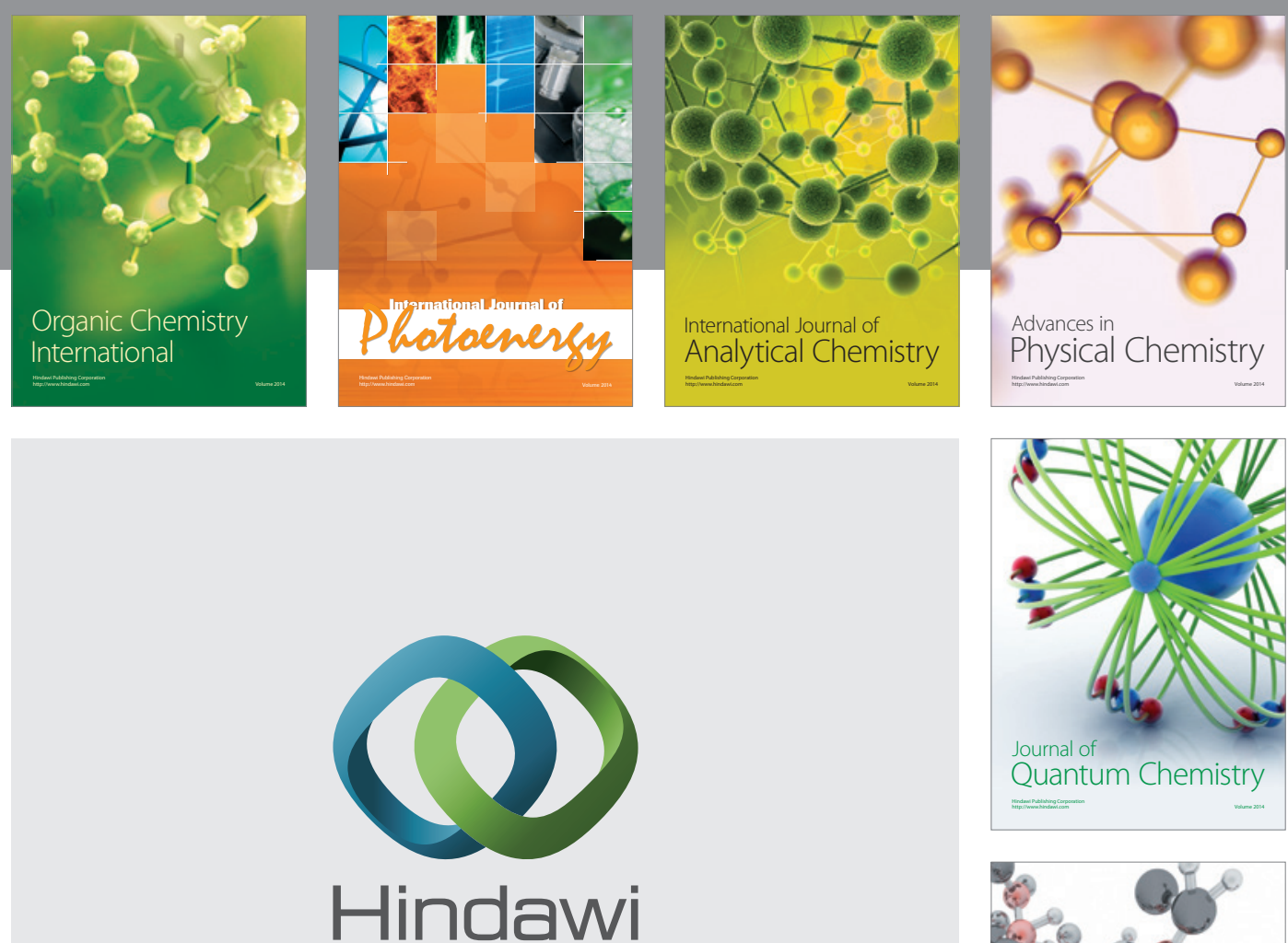

Submit your manuscripts at

http://www.hindawi.com

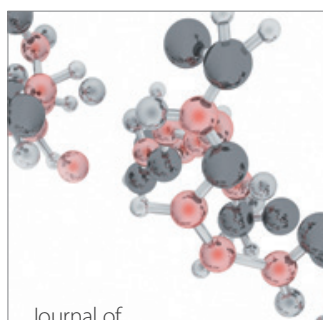

Analytical Methods

in Chemistry

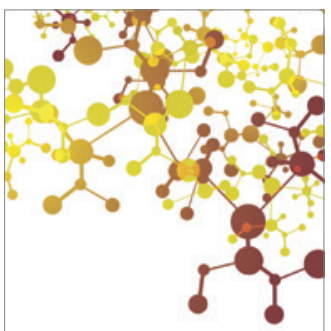

Journal of

Applied Chemistry

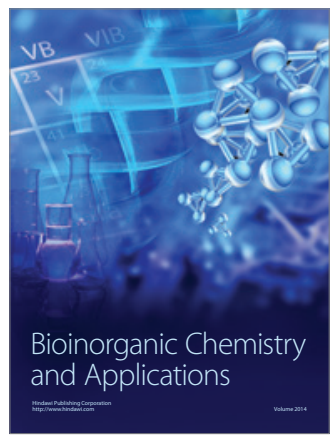

Inorganic Chemistry
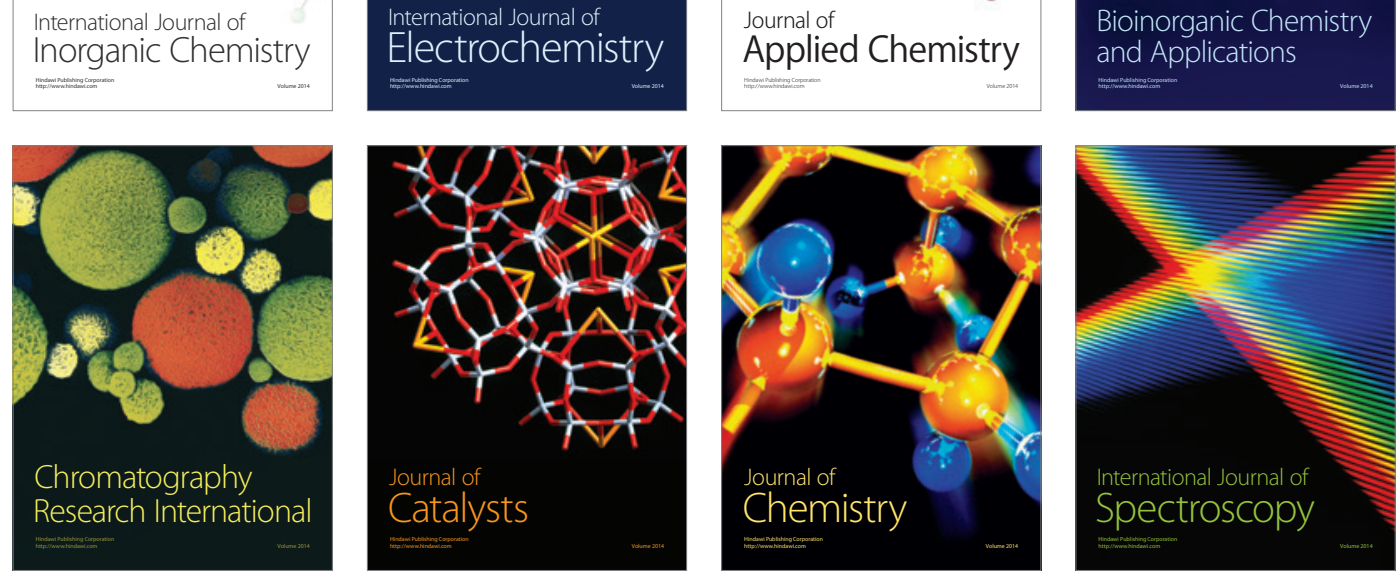